\title{
JUSTICE IN MANY ROOMS SINCE GALANTER: DE-ROMANTICIZING LEGAL PLURALISM THROUGH THE CULTURAL DEFENSE
}

\author{
MITRA SHARAFI*
}

INTRODUCTION

In the 1970s and 80s, a spirit of aggressive celebration permeated the study of legal pluralism. The romantic assumption that nonstate law was more egalitarian and less coercive than state law subtended terms like "people's law" and "folk law," and became enshrined in the names of organizations like the Netherlands-based Folk Law Circle (Volksrechtskring) and the International Union of Anthropological and Ethnological Sciences' International Commission of Folk Law and Legal Pluralism. ${ }^{1}$ Legal pluralism was more than a methodological stance intended to help lawyers and anthropologists talk to each other. It was an ideological commitment. ${ }^{2}$

Copyright $(0) 2008$ by Mitra Sharafi.

This Article is also available at http://www.law.duke.edu/journals/lcp.

* Assistant Professor of Law and History, University of Wisconsin Law School, Madison, Wisconsin. The author is grateful to Sidney Sussex College Cambridge (U.K.), Griffith University's Socio-Legal Center (Australia), and the University of Wisconsin Law School for their support while this article was being written. She also thanks Upendra Baxi, Hendrik Hartog, Stewart Macaulay, Paul McHugh, Oliver Mendelsohn, Werner Menski, Lawrence Rosen, and Prakash Shah for fruitful discussions. The views expressed here represent her position alone.

1. For use of the term "people's law," see Antony Allott \& Gordon R. Woodman, Introduction to People's Law and State Law: The Bellagio Papers 1, 2 (Antony Allott \& Gordon R. Woodman eds., 1985); Upendra Baxi, Discipline, Repression and Legal Pluralism, in LEGAL PluRAlism: PROCEEDINGS OF THE CANBERRA LAW WORKSHOP VII 51 (Peter Sack \& Elizabeth Minchin eds., 1986).

On the many meetings of the Commission on Folk Law and Legal Pluralism (est. 1978), see INDIGENOUS LAW AND THE STATE (Bradford W. Morse \& Gordon R. Woodman eds., 1988); PEOPLE's LAW AND STATE LAW: THE Bellagio PAPERS, supra, at 355; From the Editor, 23 J. LEGAL PluRALISM \& UNOFFICIAL L. v (1985); Carol J. Greenhouse \& Fons Strijbosch, Legal Pluralism in Industrialized Societies: Introduction, 33 J. PLURALISM \& UNOFFICIAL L. 1 (1993); IUAES Commission on Contemporary Folk Law, 18 AFR. L. STUD. 62 (1980).

The Dutch "Folk Law Circle" (Volksrechtskring) was established in 1976. On the use of the term "folk law" in the Dutch academic context, see John Griffiths, Recent Anthropology of Law in the Netherlands and its Historical Background, in ANTHROPOLOGY OF LAW IN THE NETHERLANDS 11, 11-66 (Keebet von Benda-Beckmann \& Fons Strijbosch eds., 1986); G. C. J. J. van den Bergh, The Concept of Folk Law in Historical Context: A Brief Outline, in AnTHropology OF LAw In THE NETHERLANDS, supra, at 67-89.

2. See P.G. Sack, Legal Pluralism: Introductory Comments, in LEGAL PlURALISM: PROCEEDINGS OF THE CANBERRA LAW WORKSHOP VII, supra note 1 , at 1. 
Marc Galanter was one of the few to hold back. In his 1981 piece, Justice in Many Rooms: Courts, Private Ordering, and Indigenous Law, he warned against glorifying nonstate law:

[I]ndigenous law... is not always the expression of harmonious egalitarianism. [Indigenous law] often reflects narrow and parochial concerns; it is often based on relations of domination; protections that are available in public forums may be absent. $^{3}$

Justice in Many Rooms is anomalous in many ways, combining as it does legal pluralism and access to justice, two themes that make little contact in the rest of the scholarship on legal pluralism. This retrospective takes Justice in Many Rooms as one of a group of pieces produced during the 1980s that fundamentally shifted the conceptual bases for the study of legal pluralism. Focusing on the pluralist side of the piece, the article traces a thread in a subsequent related literature that has given life to Galanter's 1981 reservations about the tone of the early legal-pluralist movement. ${ }^{4}$

Scholars have cooled to the view that writing about legal pluralism implies an ideological endorsement of nonstate law. The shift is particularly clear in discussions over the reasonable limits of tolerance in a multicultural society. The cultural defense debate should be read not just as a centerpiece of the multiculturalism discussion, but also as an integral part of the legal-pluralist literature-despite its rather surprising failure to make this link explicit. ${ }^{5}$

3. Marc Galanter, Justice in Many Rooms: Courts, Private Ordering, and Indigenous Law, 19 J. PLURALISM \& UNOFFICIAL L. 1, 25 (1981).

4. This article refers to the English-speaking movement specifically. Francophone work on "ethnologie juridique" and legal pluralism predates the Anglophone wave of interest. See Gordon R. Woodman, Ideological Combat and Social Observation: Recent Debate About Legal Pluralism, $42 \mathrm{~J}$. LEGAL PluRALISM \& UNOFFICIAL L. 21, 23-26 (1998) (summarizing John Gilissen's and Jacques Vanderliden's attempts to define legal pluralism in 1971). See generally John Gilissen, Introduction à l'étude comparée du pluralisme juridique, in LE PLURALISME JURIDIQUE: ÉTUDES PUBLIÉES SOUS LA DIRECTION DE JOHN GILISSEN 7-18 (John Gilissen ed., 1971); Jacques Vanderlinden, Le pluralisme juridique: essai de synthèse, in LE PLURALISME JURIDIQUE, supra, at 19-56; Jacques Vanderlinden, Return to Legal Pluralism: Twenty Years Later, 28 J. LEGAL PluRALISM \& UNOFFICIAL L. 149 (1989) (reflecting on the state of legal pluralism almost twenty years after his first paper on the subject, Le pluralisme juridique: essai de synthèse, supra).

5. For leading contributions to the multiculturalism debate among political theorists, see generally Is MUlTiCUlTURALISM BAD FOR WOMEN? 7-26 (Joshua Cohen et al. eds., 1999) (containing the title article by Susan Moller Okin, Is Multiculturlism Bad for Women?, which examines multiculturalism from a feminist perspective, and other articles responding to Okin); WILL KYMLICKA, FINDING OUR WAY: RETHINKING ETHNOCULTURAL RELATIONS IN CANADA (1999); WILL KYMLICKA, LIBERALISM, COMMUNITY AND CULTURE 1 (1989) ("[P]resent[ing] the liberal accounts of community and culture ... to evaluate their strengths and weaknesses, and to link them to the more familiar liberal views on individual rights and state neutrality."); WILL KYMLICKA, MULTICULTURAL CiTIZENSHIP: A LIBERAL THEORY OF MINORITY RIGHTS 1-2 (1995) ("[I]dentifying some key concepts and principles [of multiculturalism] ... and . . clarify[ing] the basic building blocks for a liberal approach to minority rights."); BHIKHU PAREKH, RETHINKING MULTICULTURALISM: CULTURAL DIVERSITY AND POLITICAL THEORY (2d ed. 2006) (discussing multiculturalism from a political-theory perspective); THE POLITICS OF ETHNICITY (Michael Walzer et al. eds., 1982) (containing essays discussing pluralism with regard to voting, leadership, and dual and divided loyalties); JOHN RAWLS, THE LAW OF PEOPLES: WITH, THE IDEA OF PUBLIC REASON REVISITED (1999) (proposing a model of a "Society of Peoples" that would include liberal peoples, along with nonliberal but "decent" peoples); CHARLES TAYlor, Multiculturalism: Examining the POlitics of ReCOGNition (1994) (discussing 


\section{REMEMBERING THE 80S}

In the 1980s, scholars like Marc Galanter, John Griffiths, Sally Engle Merry, Franz von Benda Beckmann, Upendra Baxi, Boaventura De Sousa Santos, and others inaugurated the legal-pluralist sequel to the "what-is-law" debate between legal positivists and natural-law advocates. Challenging legal-centralist assumptions about the state's monopoly on law, they pushed for an expansive use of the term, arguing that law referred equally to a multiplicity of nonstate, normative orders - from the rules governing schools to trade associations to the family. ${ }^{6}$ Many terms and models have been proposed. ${ }^{7}$ The most widely adopted

recognition of different ethnic and cultural communities in constitutional democracies); MICHAEL WALZER, ON TOLERATION (1997) (discussing different aspects of toleration and reflecting on multiculturalism in the United States); Amy Gutmann, The Challenge of Multiculturalism in Political Ethics, 22 PHIL. \& PUB. AFF. 171 (1993) (developing the concept of "deliberate universalism" to counter the cultural-relativism critique of legal pluralism); Will Kymlicka, Liberal Theories of Multiculturalism, in Rights, CULTURE AND THE LAw: THEMES FROM THE LEGAL AND POLITICAL PHILOSOPHY OF JOSEPH RAZ 229 (Lukas H. Meyer et al. eds., 2003) (describing the debate among political theorists over multiculturalism in western liberal democracies, and Joseph Raz's contribution to the debate); Joseph Raz, Multiculturalism: A Liberal Perspective, in RECHT IN EEN MUlticulturele SAMENLEVING 127 (N.J.H. Huls \& H.D. Stout eds., 1993) [hereinafter Liberal Perspective] (arguing against "conservative nostalgia" for the preservation of "pure exotic cultures").

6. See generally MASAJI CHIBA, LEGAL PluRALISM: TOWARD A GENERAL THEORY THROUGH JAPANESE LEGAL CULTURE (1989) (using social-scientific principles to examine legal pluralism in Japan's nonwestern legal culture); Upendra Baxi, Discipline, Repression and Legal Pluralism, in LEgal PluRAlism: PROCEedings OF THE CANBERRA LAW WORKSHOP VII, supra note 1 at 51; Boaventura De Sousa Santos, Law: A Map of Misreading. Toward a Postmodern Conception of Law, 14 J. L. \& SOC'Y 279, 297-98 (1987) (characterizing legal pluralism and the concept of interlegality as key components in a postmodern conception of law); Galanter, supra note 3, at 1-2 ("The view that the justice to which we seek access is a product that is produced-or at least distributed-exclusively by the state... is deficient."); John Griffiths, What is Legal Pluralism?, 24 J. LEGAL PLURALISM \& UNOFFICIAL L. 1, 1 ("[T] his article ... seeks to establish a descriptive conception of legal pluralism ... [which is] the presence in a social field of more than one legal order."); Sally Engle Merry, Legal Pluralism, 22 LAW \& SOC'Y REV. 869, 872 (1988) [hereinafter Merry, Legal Pluralism] ("This review discusses primarily the social science version of legal pluralism.”); Franz von Benda-Beckmann, Comment on Merry, 22 LAW AND SoC'Y REV. 897 (1988) (critiquing Merry's review, Legal Pluralism, supra); Franz von Benda-Beckmann, Who's Afraid of Legal Pluralism?, 47 J. LEGAL PLURALISM \& UNOFFICIAL L. 37, 38 (2002) ("[T] he discussions [on legal pluralism] are too strongly fixated on the law-state link and give too little attention to other aspects of the definition of law that are equally important.").

7. For examples, see generally LEgAL POLYCENTRICITY: CONSEQUENCES OF PLURALISM IN LAW (Hanne Peterson \& Henrik Zahle eds., 1995) (on "legal polycentricity"); M. Chiba, The Identity Postulate of Indigenous Law and its Function in Legal Transplantation, in LEGAL PLURALISM: PROCEEDINGS OF THE CANBERRA LAW WORKSHOP VII, supra note 1, at 33 (on "indigenous law").

The term "legal polycentricity" has not consistently been distinguished from legal pluralism. Compare Lars D. Eriksson et al., Introduction: A Polytical Manifesto, in LEGAL POLYCENTRICITY: CONSEQUENCES OF PLURALISM IN LAW, supra, at 8 (arguing that "legal polycentricity" differs from "legal pluralism" because it approaches law from within the discipline of law, rather than from the "outside" perspective of social science) with Henrik Zahle, The Polycentricity of the Law or the Importance of Legal Pluralism for Legal Dogmatics, in LEGAL POLYCENTRICITY: CONSEQUENCES OF PLURALISM IN LAW, supra, at 189 (using "legal polycentricity" and "legal pluralism" synonymously).

For examples of other proposed terms, see also De Sousa Santos, supra note 6 (on "interlegality"); Peter Fitzpatrick, Law and Societies, 22 OSGOODE HALL L.J. 115, 115 (1984) (on "integral plurality"); Galanter, supra note 3, at 17-27 (on "indigenous ordering"); Stewart Macaulay, Private Government, in LAW AND SOCIAL SCIENCES 445 (Leon Lipson \& Stanton Wheeler eds., 1986) (on "private 
is Sally Falk Moore's notion of the "semi-autonomous field," a normative order defined by "the fact that it can generate rules and customs and symbols internally," but "is also vulnerable to rules and decisions and other forces emanating from the larger world by which it is surrounded."

The work of Galanter and his colleagues brought about two major changes in the conception of legal pluralism. The first was the shift from the understanding of legal pluralism as a plurality of norms administered by the state - the model embodied by Hooker's classic study-to an understanding of a plurality existing beyond the state. ${ }^{9}$ The second was an attempt to get beyond Hooker in a geographical sense. What Sally Merry calls the "new legal pluralism" was born out of the shift from seeing legal pluralism as a colonial or post-colonial phenomenon in the nonwestern world, to one that exists equally in industrialized, largely western contexts. ${ }^{10}$

III

\section{THE CUlTural DEFENSE}

Since the 1980s, excellent work on legal pluralism has been done by scholars who do not explicitly so identify their subject. The best instance of this "unofficial" work on unofficial law is the debate over the cultural defense. The defense has potential applications across civil and criminal domains. ${ }^{11}$ However, the literature has focused upon its feasibility as a partial defense to murder.

government"); Walter O. Weyrauch \& Maureen Anne Bell, Autonomous Lawmaking: The Case of the 'Gypsies,' in GYPSY LAW: ROMANI LEGAL TRADITIONS AND CULTURE 11 (Walter O. Weyrauch ed., 2001) (on the "autonomous lawmaking" of the Romani people).

8. Sally Falk Moore, Law and Social Change: the Semi-Autonomous Social Field as an Appropriate Subject of Study, 7 LAW \& SOC'Y REV. 719, 720 (1973); see also SALLY FALK MOORE, LAW AS PROCESS: AN ANTHROPOLOGICAL APPROACH 54 (1978); WERNER MENSKI, COMPARATIVE LAW IN A GLOBAL CONTEXT 104-08 (2006).

9. See M.B. HoOKer, Legal Pluralism: An InTroduction to Colonial and NeOColonial LAWs 1 (1975); Anne Griffiths, Legal Pluralism, in AN INTRODUCTION TO LAW AND SOCIAL THEORY 289, 290-98 (Reza Banakar \& Max Travers eds., 2002).

10. See Merry, Legal Pluralism, supra note 6, at 872. See also Masaji Chiba, Legal Pluralism in Mind: A Non-Western View, in LEGAL POLYCENTRICITY: CONSEQUENCES OF PluRALISM IN LAW, supra note 7, at 74; John Griffiths, Legal Pluralism and the Theory of Legislation-With Special Reference to the Regulation of Euthanasia, in LEGAL POLYCENTRICITY: CONSEQUENCES OF PLURALISM IN LAW, supra note 7, at 201; see generally 33 J. LEGAL PLURALISM \& UNOFFICIAL L. (1993) (containing articles about legal pluralism in industrialized societies).

11. For civil and criminal contexts falling short of murder, see ALISON DUNDES RENTELN, THE Cultural Defense 48-182 (2004) [hereinafter RENTEln, The Cultural Defense] (addressing minority cultural elements of criminal and civil cases pertaining to homicide, children, drugs, animals, marriage, attire, and the dead). For a lesser criminal context, see Mother 'Cut Boys' Faces in Tribal Ritual', THE Times, July 16, 1974, at 3 (detailing the case of $R$. v. Adesanya, in which a mother performed Nigerian ritual scarification upon her two sons in the United Kingdom and attempted to argue for a cultural defense); Discharge for Mother in Tribal Cuts Case, THE TIMES, July 17, 1974, at 4 (describing how the judge in $R$. v. Adesanya found the Nigerian mother guilty of assault, but ordered an absolute discharge on the grounds that the mother did not realize she was breaking the law). See also Renteln, The Cultural Defense, supra, at 49-51 (discussing the R. v. Adesanya case); Alison Dundes Renteln, Is the Cultural Defense Detrimental to the Health of Children?, in LAW \& ANTHROPOLOGY: INTERNATIONAL YEARBOOK FOR LEGAL ANTHROPOLOGY VOL. 7 29-31 (Rene Kuppé \& Richard Potz eds., 1994) [hereinafter Is the Cultural Defense Detrimental?]. 
Should an individual convicted of murder have his or her sentence reduced (typically from a mandatory life sentence to a discretionary sentence) if it can be proven that he or she was reacting to a culturally specific act of provocation? The triggering act would not be considered inflammatory to the same degree, if at all, according to the norms of the host society.

Across the common-law and western world, an array of cultural norms and scenarios have produced opportunities to employ this defense. ${ }^{12}$ The classic examples entail violence against women. In an Australian case, a Turkish immigrant father murdered his teenaged daughter for engaging in premarital sex, claiming that her behavior constituted provocation to a person of his cultural and religious background. ${ }^{13}$ In a well-known American case, a Hmong man accused of kidnapping and raping an underaged woman of his community in California, argued that he had carried out the Laotian tradition of "marriage by capture" (zij poj niam).$^{14}$ In another case, a Chinese man living in New York smashed his wife's skull with a claw hammer upon discovering that she had been unfaithful, claiming that a wife's adultery is particularly shameful in Chinese culture. ${ }^{15}$

The defense has been attempted by women, too. A conservative Lebanese woman living in Australia killed a male relative when he made sexual advances, claiming that her response was appropriate by her own cultural norms. ${ }^{16} \mathrm{~A}$ Japanese woman living in California drowned her two children and attempted to kill herself upon learning of her husband's extramarital affair. She argued that she had attempted to perform Japanese ritual parent-child suicide (oya-ko shinju), a tradition whose existence was confirmed by a petition signed by 25,000 members of the Los Angeles Japanese community. ${ }^{17}$ Several aboriginal

12. For an extensive list of case references (mainly American), see RENTELN, THE CULTURAL DEFENSE, supra note 11, at 321-29. For a similar list covering English, Australian, and Indian authorities, see Stanley Yeo, UnRESTRAINED KILlings AND THE LAW: PROVOCATION AND EXCESSIVE SELF-DEFENSE IN INDIA, ENGLAND AND AUSTRALIA xiii-xix (1998).

13. R. v. Dincer (1983) 1 V.R. 460.

14. People v. Moua, No. 315972-0 (Cal. Super. Ct. Feb. 7, 1985). See generally RENTELN, THE CUlTURAL DeFENSE, supra note 11, at 126-28; Doriane Lambelet Coleman, Individualizing Justice Through Multiculturalism: The Liberals' Dilemma, 96 COLUM. L. REV. 1093, 1105-07 (1996); Neal A. Gordon, Implications of Memetics for the Cultural Defense, 50 DUKE L.J. 1809, 1830 (2001); Nancy S. Kim, The Cultural Defense and the Problem of Cultural Preemption: A Framework for Analysis, 27 N.M. L. REV. 101, 123-24 (1997); Choua Ly, Conflict Between Law and Culture: The Case of the Hmong in America, 2001 Wis. L. REV. 471, 478-81, 484-86 (2001); Susan Moller Okin, Is Multiculturalism Bad for Women?, in Is MUlTiCUlTURALISM BAD FOR WOMEN?, supra note 5, at 18; Nilda Rimonte, $A$ Question of Culture: Cultural Approval of Violence Against Women in the Pacific-Asian Community and the Cultural Defense, 43 STAN. L. REV. 1311, 1319-20 (1991).

15. People v. Dong Lou Chen, No. 87-7774 (N.Y. Sup. Ct. Dec. 2, 1988). See Daina C. Chiu, Cultural Defense: Beyond Exclusion, Assimilation, and Guilty Liberalism, 82 CAL. L. REV. 1053, 1053 (1994); Alice J. Gallin, The Cultural Defense: Undermining the Policies Against Domestic Violence, 35 B.C. L. REV. 723, 729-31 (1994); Kim, supra note 14, at 102; Rimonte, supra note 14, at 1311; Leti Volpp, (Mis)Identifying Culture: Asian Women and the "Cultural Defense," 17 HARV. WOMEN's L.J. 57, 64-77 (1994).

16. See R. v. Saliba, 10 CRIM. L.J. 420 (1986) (summarizing the case from New South Wales).

17. People v. Kimura, No. A-091133 (L.A. Super. Ct. Nov. 21, 1985). See also Kim, supra note 14, at 117-19. See generally Taimie L. Bryant, Oya-Ko Shinju: Death at the Center of the Heart, 8 UCLA 
Australian women killed a white Australian man in a drunken brawl after he called one a "black bitch" and another a "slut." They told the court that by aboriginal norms, their violence was the correct response to his insults. ${ }^{18}$

Courts have generally been reluctant to endorse the defense. ${ }^{19}$ But academic discussants like Renteln, Yeo, and others have been more receptive..$^{20}$ Against them is the claim that the cultural defense is impracticable: cultural practices are so time-bound, region-specific, class-based, malleable, and at times contested, as to be effectively unidentifiable and certainly unenforceable. ${ }^{21}$ Joseph Raz has made the alternative argument that there is nothing inherently sacred about culture, even when it is determinable..$^{22}$ The point is particularly relevant, given a phenomenon often manifested by immigrant groups: the intensification of perceived traditional values in comparison to current social views not only in the host society, but also in the society of origin. ${ }^{23}$

The subculture problem is another serious challenge to the cultural defense-or else a reason to extend its ambit. ${ }^{24}$ If special exceptions are made for other cultures in our midst, why not for home-grown subcultures as well? If the teenaged "Goth" has a choice in choosing his or her subculture, is it fair to say that the second-generation Wahhabi Muslim exercises no agency in choosing which elements of minority and majority culture to adopt, even if he

PAC. BASIN L.J. 1 (1990); Yuko Kawanishi, Japanese Mother-Child Suicide: The Psychological and Sociological Implications of the Kimura Case, 8 UCLA PAC. BASIN L. J. 32 (1990). On a case with similar facts, see Kim, supra note 14, at 127.

18. See Diane Bell, Exercising Discretion: Sentencing and Customary Law in the Northern Territory, in INDIGENOUS LAW AND THE STATE, supra note 1, at 367-68. For another aboriginal case involving the cultural defense, see Regina. v. Muddarubba, in Stanley Meng Heong Yeo, Ethnicity and the Objective Test in Provocation, 16 MelB. U. L. REV. 67, 69 (1987) (discussing the 1957 Australian case). See also James Crawford, Peter Hennessy \& Mary Fisher, Aboriginal Customary Laws: Proposals for Recognition, in INDIGENOUS LAW AND THE STATE, supra note 1, at 50.

19. On the U.S. context, see RENTELn, The Cultural DeFEnSE, supra note 11, at 186 . The Australian Law Reform Commission recommended enabling the partial defense through legislation, a suggestion that was not implemented. See Aus. L. Reform Comm'n, ALRC 31-The Recognition of Aboriginal Customary Laws, 1986, http://www.austlii.edu.au/au/other/alrc/publications/reports/ 31/pdf_index.html (last visited Mar. 4, 2008) (follow "ALRC 31 Vol. 1" and "ALRC 31 Vol. 2" hyperlinks).

20. See Renteln, The Cultural Defense, supra note 11, at 188; LeOn SHelefF, The Future OF TRADITION: CUSTOMARY LAW, COMMON LAW AND LEgAL PLURALiSM 262-89 (2000); MalekMithra Sheybani, Cultural Defense: One Person's Culture is Another's Crime, 9 LOY. L.A. INT'L \& COMP. L.J. 751 (1986-87); Yeo, supra note 18, at 68; Note, The Cultural Defense in the Criminal Law, 99 HARV. L. REV. 1293 (1986). But see PRAKASH SHAH, LEgAl PluRAlism in CONFLict: COPING WITH CULTURAL DIVERSITY IN LAW 20, 67-87 (2005) (offering a more radical, conflict-of-laws approach).

21. See Coleman, supra note 14, at 1162; Kim, supra note 14, at 115; Ly, supra note 14, at 489-94. But see ReNTELn, THE CUlTURAL DefENSE, supra note 11, at 207-10 (arguing that despite limits to how the cultural defense may be used, it is still viable, and its application requires a "case-by-case approach").

22. See Raz, Multiculturalism: A Liberal Perspective, supra note 5, at 139-40.

23. A reified sense of tradition is one component of what has been called "Patelism" in the U.K. context. Anu Garg, Patelism, A Strategy, And Indian Doctors' Well-Being, Presentation at the 2007 British Association of South Asian Studies Annual Conference at Cambridge (Mar. 30, 2007).

24. See William I. Torry, Multicultural Jurisprudence and the Culture Defense, 44 J. LEGAL PluRALISM \& UNOFFICIAL L. 127-61 (1999) (advocating an extension of the cultural defense). 
or she opts for religious associations that represent a marginal subculture themselves? $?^{25}$ As Shah has argued, the cultural defense assumes that only some ethnic minorities possess cultures, while "white (and black) people do not." ${ }^{26}$

The most powerful critique of the cultural defense is the feminist one. A group of American feminist scholars, many of whom identify themselves as female lawyers of East and Southeast Asian descent, argue that the cultural defense decriminalizes violence against minority women, whom they argue are the most common victims in these cases. ${ }^{27}$ In "the ultimate trap for a woman of color," the cultural defense casts gender power against racial (or more accurately, cultural) solidarity. ${ }^{28}$ Where the courts have been sympathetic to the cultural defense, many Asian American communities have understood themselves to be operating in a law-free space in which violence against women will be tolerated. Women from these communities are less likely to seek the protection of the law. Many feel the state has abandoned them, albeit out of a liberal sense of cultural sensitivity. ${ }^{29}$ Echoing elements of the larger discussion amongst political theorists, writers like Rimonte, Volpp, Kim, Choi, Gallin, and Chiu have argued that multiculturalism (in this particular form) is indeed bad for women. ${ }^{30}$

IV

\section{CONCLUSION}

Since the 1980s, it has been generally accepted that legal-pluralist scholarship has left the colonial childhood home for good. ${ }^{31}$ In fact, there have been frequent visits back. This multicultural turn has meant that work on nonstate, nonethnic norms in western contexts has been drowned out by the deluge of work on immigrant and indigenous people's normative orders, themselves replete with post-colonial resonances. ${ }^{32}$ Galanter and his colleagues

25. The American case law on religious minorities (which deals largely with minorities of vaguely protestant, European background) could provide insights on the subculture problem. See Sherbert v. Verner, 374 U.S. 398 (1963) (Seventh-Day Adventists); Wisconsin v. Yoder, 406 U.S. 205 (1972) (the Amish). On cases involving Christian Scientists, see Renteln, Is the Cultural Defense Detrimental?, supra note 11 , at $48-53,64-67$.

26. SHAH, supra note 20 , at 86 .

27. For critiques of the cultural defense, see generally Chiu, supra note 15; Carolyn Choi, Application of a Cultural Defense in Criminal Proceedings, 8 UCLA PAC. BASIN L.J. 80 (1990); Coleman, supra note 14, 1162-65; Gallin, supra note 15, at 745; Kim, supra note 14; Rimonte, supra note 14.

28. See Chiu, supra note 15, at 1121. See also Coleman, supra note 14; Anne Phillips, When Culture Means Gender: Issues of Cultural Defense in the English Courts, 66 MOD. L. REV. 510 (2003).

29. See Gallin, supra note 15 , at 735-36.

30. See Choi, supra note 27, at 89; Chiu, supra note 15, at 1121-24; Gallin, supra note 15, at 735; Kim, supra note 14, at 131; Rimonte, supra note 14, at 1319; Volpp, supra note 15, at 75 . See generally PAREKH, IS MULTICULTURALISM BAD FOR WOMEN?, supra note 5.

31. See Merry, Legal Pluralism, supra note 6, at 872.

32. For a sample of the avalanche of work on ethnic minority norms, see 51 J. LEGAL PLURALISM \& UNOFFICIAL L. (2005) (containing articles on "multicultural interlegality"); Michael Humphrey, Community Disputes, Violence and Dispute Processing in a Lebanese Muslim Immigrant Community, 
writing in the 1980s may not have predicted the reemergence of these colonial associations. But Galanter did warn against the tendency to celebrate nonstate law as inherently less objectionable than state law-a view made repeatedly in the discussion of ethnic minority norms, particularly from a feminist perspective. Through the quest for a workable model of tolerance in a multicultural society, what has emerged since 1981 is a less polemical and politically invested approach to legal pluralism.

Work on the cultural defense has exposed binaries that complicate the earlier division between left-leaning pluralists and legal centralists, adding the feminist-versus-pluralist opposition into the mix. This antagonistic constellation deserves more attention than it has received, not just from scholars of legal pluralism, but also from those writing on ethnic minorities and law, a field that is particularly well developed in the United Kingdom. ${ }^{33}$ At very least, discussants of legal pluralism and the cultural defense need to see themselves as connected. Critics of the cultural defense have made an important intervention in the legal-pluralist literature, giving muscle to Galanter's discomfort with the tone of the early legal-pluralist movement. Why neither side has acknowledged it remains a mystery.

22 J. Legal Pluralism \& UnOfFicial L. 53 (1984); Fons Strijbosch, Ancestors in the Law of Moluccans in the Netherlands, 33 J. Legal PluRAlism \& UnOFFICIAL L. 53 (1993); Fons Strijbosch, Self-Redress and Feud: Among Moluccans in the Netherlands, 32 J. LEGAL PlURALISM \& UNOFFICIAL L. 47 (1992). See also GYPSY LAW, supra note 7. Even recent work on commercial "cultures" like the diamond trade often has an ethnic component. See Oliver Mendelsohn, How Indian is Indian Law?, in Enculturing Law: New Agendas For Legal Pedagogy (Mathew John \& Sitharamam Kakarala eds., 2007) 146-48 (on the Jain diamond merchants of Palanpur, India); Barak D. Richman, How Community Institutions Create Economic Advantage: Jewish Diamond Merchants in New York, 31 LAW \& SOC. INQUIRY 383 (2006) (addressing orthodox Jewish diamond traders in New York). To compare with works discussing trade cultures' norms, see Galanter, supra note 3, at n.34.

33. For examples of works on ethnic minorities and law, see SEBASTIAN POULTER, ENGLISH LAW AND ETHNIC MINORITY CUSTOMS (1986); DAVID PEARL \& WERNER MENSKI, MUSLIM FAMILY LAW 51-83 (1998) (examining Muslim law in Britain); Werner Menski, Law, Religion and South Asians in Diaspora, in RELIGIOUS RECONSTRUCTION IN THE SOUTH ASIAN DIASPORAS: FROM ONE GENERATION TO ANOTHER (John R. Hinnells ed., 2007) 243-64; SHAH, supra note 20. 